\title{
Cattle Manure Disposal on Potato Growing Fields in Conditions of the Southern Forest-Steppe of the Bashkortostan Republic
}

\author{
Elina Shafeeva $^{1 *}$, Alexander Komissarov ${ }^{1}$, Marat Ishbulatov ${ }^{1}$, \\ Khalil Safin², Florid Davletshin ${ }^{1}$ \\ ${ }^{1}$ Department of Real Estate Cadastre and Geodesy, Federal State Budgetary Educational Establishment \\ of Higher Education "Bashkir State Agrarian University," Ufa, Russian Federation \\ ${ }^{2}$ Department of land management, Federal State Budgetary Educational Establishment of Higher Education \\ "Bashkir State Agrarian University," Ufa, Russian Federation
}

Received: 25 June 2020

Accepted: 27 September 2020

\begin{abstract}
Higher yields of environmentally friendly potato require more organic fertilizers and irrigation. The most common organic fertilizer is cattle manure. The research goal is to study the effect of irrigation and high rates of cattle manure used in conditions of the southern forest-steppe of the Bashkortostan Republic on the yield and quality of potato tubers. The conducted study demonstrates increased potato tuber growth from 0.12 to $0.72 \mathrm{~kg} / \mathrm{plant}$ and 0.30 to $0.79 \mathrm{~kg} / \mathrm{plant}$ with a higher rate of cattle manure (120 t/ha) under rainfed and irrigation conditions, respectively. Cattle manure disposal is one of the most acute issues in terms of environmental conservation. It is a great concern in farming practice worldwide that requires the scientifically-proven use of farmyard manure. To get consistently high yields of crops and maintain soil fertility becomes possible when taking into account local agro-meteorological and soil conditions. The optimal rates of cattle manure for potatoes cultivated on leached chernozem in the southern forest-steppe of the Republic of Bashkortostan under irrigation and rainfed conditions were found. Potato growing at different rates of cattle manure application has been studied. There is an economic assessment of efficiency to apply different rates of manure.
\end{abstract}

Keywords: cattle manure, organic fertilizer, potatoes, recycling

\section{Introduction}

The potato is the most important food crop, indispensable for food and other industries [1-4]. Around 19 million hectares of land across the world are

*e-mail: elinashafeeva@yahoo.com shafeeva20081@rambler.ru used for growing potatoes. Their total yield is $328 \mathrm{mln}$ tons. To date, the Russian Federation is the third-largest potato producer in the world (more than 29.5 million tons of potato in 2012) after China (about 86 million tons) and India (more than 44 million tons) [5].

Currently, there is a lack of a developed technology of manure use in plant growing [6]. This cheap fertilizer is being used irrationally. There are large stocks of farmyard manure around cattle breeding enterprises 
and farms. It causes significant damage to the environment. A wise solution is to use cattle manure in plant growing. It can increase crop yields and improve soil fertility. Thus, it is critical to study the effect of different rates of cattle manure on the yield and quality of potato tubers grown in the south-steppe black leached soil of Bashkortostan. Sustainable agriculture can be achieved by using organic fertilizers.

Mineral fertilizers have a great impact on the environment [7]. Improper manure contains toxic impurities [8]. Unsatisfactory fertilizers can result in serious negative consequences: lower quality of agricultural products, soil salination, and acidification $[9,10]$. Another concern is the high cost of mineral fertilizers [11, 12]. Currently, nitrogen-phosphoruspotassium is 20,304 rubles/t, nitrogen-phosphoruspotassium-sulphur is 28067 rubles/t.

Crop growing without fertilizers brings in higher acidity [13], reduced base saturation, draining [14], poor soil fertility. Removal of nutrients is not compensated with their supply [15], while the application of mineral fertilizers leads to higher acidity. This problem can be solved by using organic fertilizers. Disposal of manure is being discussed across the world. In Nigeria, manure is used in the development of the fishery industry and aquaculture. It solves the problem of manure disposal [16]. O'Callaghan et al. [17] claim that soil fertilization should be the primary method of cattle manure disposal, as it normalizes the balance of nutrients in the soil: plants harvested take out nutrients being restored by application of manure.

In south-eastern Nigeria, intensive use of fertilizers in growing sweet potatoes depleted nutrients in the soil. Over the years, due to financial difficulties, farmers could not buy expensive chemical fertilizers, and the latter was replaced with cattle manure. As a result, the soil condition and yield of sweet potatoes improved [7]. Studies conducted in Alberta, Canada, have shown that $40 \mathrm{~g}$ of cattle manure per $1 \mathrm{~kg}$ of soil reduces its acidity by an average 1 unit of $\mathrm{pH}[18]$.

Balemi [19] claims that $10-30 \mathrm{t} /$ ha of the manure is equivalent to $33.3 \%$ and $66.6 \%$ of nitrogen-phosphorus inorganic fertilizers, respectively, without a significant reduction in the total number and quality of potato tubers.

Iranian scientists suggest using manure together with chemical fertilizers. According to their findings, the maximum output of potato tubers $(36.8 \mathrm{t} / \mathrm{ha})$ was harvested when $20 \mathrm{t}$ of manure was combined with $150 \mathrm{~kg} / \mathrm{ha}$ of nitrogen [20]. Optimum rates of manure are found according to the characteristics of naturalclimatic zones, topography, type of soil, and nutrient availability. For most Russian regions, the most effective application of cattle manure for potato growing is at the rate of 20-40 t/ha. Studies conducted in the premountain subprovince of the Republic of Dagestan have shown that the application of $10,20,30,40$, and $50 \mathrm{t} /$ ha of manure in dark-chestnut soils contributed to potato yields; $7.8 ; 12.9 ; 16.6 ; 18.3$, and 19.7 t/ha respectively [21].

In this research, cattle manure is offered to be disposed of in potato growing. Being used according to a scientifically sound and systematic approach, it can be an indispensable organic fertilizer and a source of additional income. Cattle manure in potato growing technology for soil and climatic conditions of the southern forest-steppe of the Bashkortostan Republic remains poorly studied. Therefore, this paper is aimed to study the effect of high rates of farmyard manure and irrigation on the yield and quality of potato tubers grown in conditions of this area.

\section{Experimental Procedures}

Ninety thousand hectares of land in Bashkortostan are used for growing potatoes. It is about $4 \%$ of the total area of the Russian Federation under potatoes. According to the Russian Federal State Statistics Service, Bashkortostan ranks the fifth among other subjects of the country (after the Voronezh district, the Krasnoyarsk and Altai territories, the Republic of Tatarstan). They are the leading suppliers of potato to the domestic market. Potato yield was $126 \mathrm{c} / \mathrm{ha}$ in 2015 and $123.1 \mathrm{c} /$ ha in 2016),

The efficiency of different rates of cattle manure used for the leached chernozem in the southern foreststeppe of Bashkortostan was studied in conditions of dryland and irrigation. A field experiment was conducted on the water-balance station of the Bureau for Land Reclamation and Agricultural Water Supply in 2014-2016.

According to the B.A. Dospekhov's methodology [22], field research includes experiment planning, observation, and accounting, land selection and preparation, field experiment establishment and performance methods, the basics of statistical analysis as well as a simple and multifactorial mathematical processing of field and vegetation experiment results. The conducted experiment relied on the only difference method. All conditions had to be the same, except for the condition under the study that was different rates of manure and soil moisture. The research target was the most common middle-early potato of the Nevsky variety. The area of the registration plot is $16 \mathrm{~m}^{2}$.

The field experience was to study the impact of cattle manure on crop yields and the quality of potato tubers grown with or without irrigation. 40, 60, 80, 100 , and $120 \mathrm{t} /$ ha of farmyard manure was introduced in spring, during soil treatment. The forecrop was fallow.

The soil on the experimental site is leached chernozem. It is low potent, medium humus, slightly eroded alluvial-diluvial carbonate clay.

The arable layer contains $6.1 \%$ of humus (the soil humus content was measured by the Tyurin's 
method in the modification of CINAO (Russian national standard GOST 26213-91), $154 \mathrm{mg} / \mathrm{kg}$ of alkaline hydrolyzed nitrogen (determined by a CINAO method (Russian national standard GOST 26486-85), $4.4 \mathrm{mg} / \mathrm{kg}$ of labile phosphorus, and $75 \mathrm{mg} / \mathrm{kg}$ of exchangeable potassium (the phosphorus and potassium content was estimated by the Chirikov's method in the modification of CINAO (Russian national standard GOST 26204-91). The soil medium reaction is subacid ( $\mathrm{pH}=5.0)$. The chemical composition of cattle manure is given in Table 1. The nitrogen content was evaluated according to I. Romashkevich's colorimetric analysis [23], the phosphorus concentration was found by Denise's procedure. The content of organic matter was found using the thermogravimetrymass spectrometry (Russian national standard GOST 27980-88).

Table 1 demonstrates the alkaline $\mathrm{pH}$ value of manure.

Soil conditions are mainly favorable for potato growing though they require additional organic or mineral fertilizers and irrigation.

During the conducted experiment, weather conditions were characterized by extremely uneven natural moisture and fluctuations in average daily air temperatures: the vegetation period of 2014 was characterized as very dry (Selyaninov's hydrothermal coefficient $(\mathrm{HTC}=0.69), 2015-$ dry $(\mathrm{HTC}=0.77), 2016$ - very dry $(\mathrm{HTC}=0.56)$. According to meteorological conditions, it is clear that the production of potatoes requires additional soil moisture in the form of vegetative irrigation.

Annually, at the end of September, the soil was prepared by the primary tillage and autumn plowing. The soil was cultivated and harrowed after spring tilth. Before potato was planted, organic fertilizers were applied by hand and closed with a cutter. Potato tubers were treated with «Prestige» insectofungicide (manufactured by the Bayer Company, Germany) to protect against pests and diseases.

In 2014 and 2015, the potato was planted on May 29-31 and harvested on September 2-6. In 2016, there was early spring. Planting was performed on May 7. Accordingly, the subsequent phenological phases took place earlier than the average time. Three-year average vegetation period of potato was 115 days (from planting to harvesting).

There was a regular analysis of the soil moisture in the calculated soil layer of $0-50 \mathrm{~cm}$ to find optimal irrigation rates.

\section{Results}

Before considering the results of the potato study, it is necessary to characterize the results on soil moisture. Observations showed that in 2014 under the rainfed scheme, there was soil moisture deficiency from the moment of potato planting until the emergence (June 17) and from the beginning of top wilting (July 30) until the end of the growing season. In 2015, moisture deficiency lasted from the beginning of the flowering phase (July 20) until the end of the growing season. In 2016, the shortage of soil moisture was observed during budding (from May 25 to June 5), then from the beginning of flowering to full bloom (June 22 - June 27) and from the end of flowering (July 23) until the harvest.

Optimal soil moisture was provided by sprinkling using the "Tuchka" installation. The moisture content of the calculated soil layer in irrigated areas was maintained in the range from 70 to $100 \%$ of the lowest moisture content. These are optimal conditions for potato growing. Irrigation and watering rates were directly dependent on the prevailing meteorological conditions during the growing season. The irrigation rate varied from 643 to $2350 \mathrm{~m}^{3} / \mathrm{ha}$. Watering rates depended on pre-irrigation soil moisture and meteorological forecasts.

On average, for three years of research, the amount of potato water consumption was $255 \mathrm{~mm}$ on irrigated plots, and $194 \mathrm{~mm}$ on non-irrigated fields. The average daily water consumption of potatoes for three years was average $2.2 \mathrm{~mm}$ in irrigated areas and $1.7 \mathrm{~mm}$ in rainfed ones. The study of the potato structure development with introducing different rates of cattle manure showed that higher fertilizer rates resulted in larger aboveground part and higher yield of potato tubers (Fig. 1).

When examining the weight dynamics of potato tubers at different rates of manure, the following results were obtained (Fig. 2).

The study of the potato tuber growth showed its active increase with higher cattle manure rate of $120 \mathrm{t} / \mathrm{ha}$ both under rainfed and irrigation conditions (from 0.12 to $0.72 \mathrm{~kg} /$ plant and from 0.30 to $0.79 \mathrm{~kg} /$ plant, respectively). When fertilizers were not applied, there was a slower growth of tubers on irrigated plots (from 0.08 to $0.31 \mathrm{~kg} /$ plant) and rainfed fields (from 0.16 to $0.5 \mathrm{~kg} /$ plant).

The application of cattle manure had a strong influence on potato stems (Fig. 3).

Potato stems reached the highest height at full blossom. With lower turgor pressure in stems, plants from the state of growth went to withering. Plant height

Table 1. Chemical composition of organic fertilizers.

\begin{tabular}{|c|c|c|c|c|c|}
\hline \multirow{2}{*}{ Type of organic fertilizer } & \multirow{2}{*}{ Humidity, \% } & \multicolumn{4}{|c|}{ The contents in the air-dry matter } \\
\cline { 3 - 6 } & & $\mathrm{pH}$ & Organic substance, $\%$ & Nitrogen, \% & Phosphorus, \% \\
\hline Cattle manure & 43.1 & 7.9 & 69.5 & 2.1 & 0.6 \\
\hline
\end{tabular}




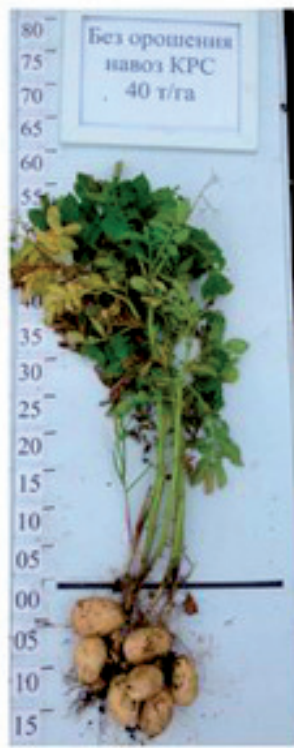

40 tha of manure

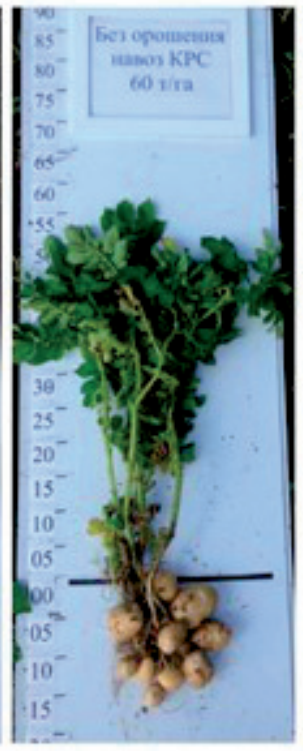

60 tha of manure
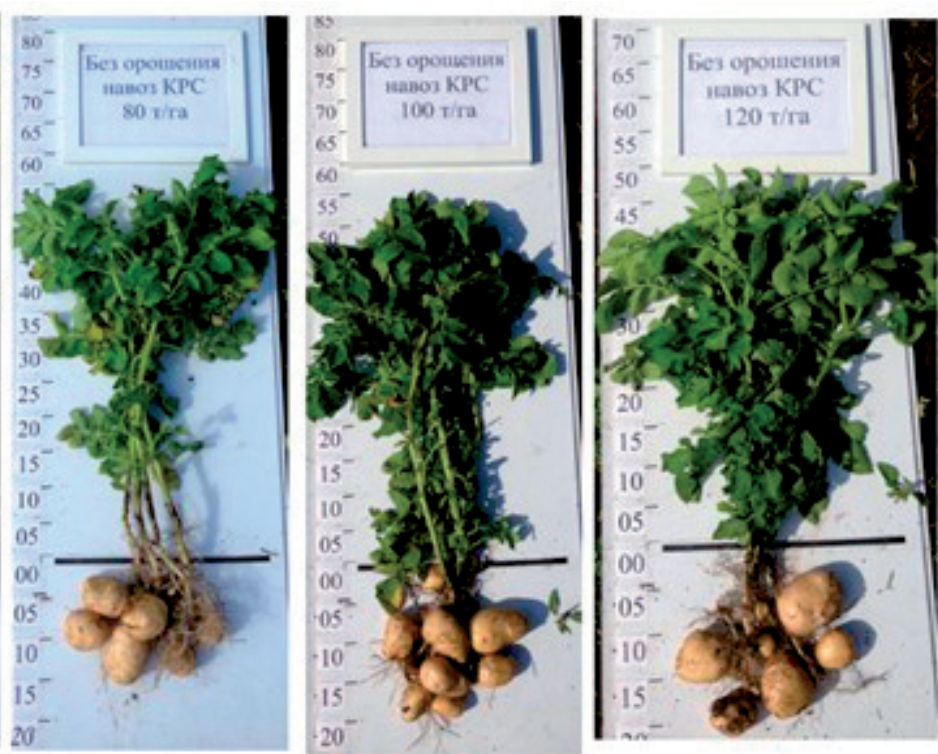

$80 \mathrm{t}$ ha of manure $100 \mathrm{t}$ ha of manure

\section{0 tha of manure}

Fig. 1. Potato structure. Beginning of the top wilting. Non-irrigated areas.

varied from 27 to $42 \mathrm{~cm}$. The maximum height was observed on the plot with manure applied at the rate of $120 \mathrm{t} / \mathrm{ha}$ (42 and $47 \mathrm{~cm}$ on the dryland and irrigated field correspondently).

Higher rates of fertilizers contributed to the larger aboveground part of the plants (from 0.13 to $0.23 \mathrm{~kg}$ / plant) (Table 2). The largest weight of the top was on the site with introduced cattle manure at the rates of 80 $\mathrm{t} / \mathrm{ha}$ on the rainfed field and $120 \mathrm{t} / \mathrm{ha}$ on the irrigated land. The lowest top weight was on the control plot, having been watered and fertilized with cattle manure.

The analysis showed that the application of cattle manure increased biological yield from 14.1 to 24.6 $\mathrm{t} /$ ha on the dryland and from 20.2 to $31.1 \mathrm{t} / \mathrm{ha}$ on the irrigated plot. The highest yield was obtained when applying $120 \mathrm{t} /$ ha of manure (Fig. 4).

In potato production, the marketability of tubers is essential (Table 3).

When applying cattle manure under irrigation, the highest marketable value of tubers $(76 \%)$ was obtained on the plot with a rate of $40 \mathrm{t} / \mathrm{ha}$, under rainfed condition (marketable value $80 \%$ ) on the plot with the rate of $100 \mathrm{t} / \mathrm{ha}$.

Different rates of cattle manure had different effects on the quality of potato tubers. Starch is the most important carbohydrate. It determines the nutritional value of potatoes, as well as its caloric content and friability during cooking. It is the main dry matter in

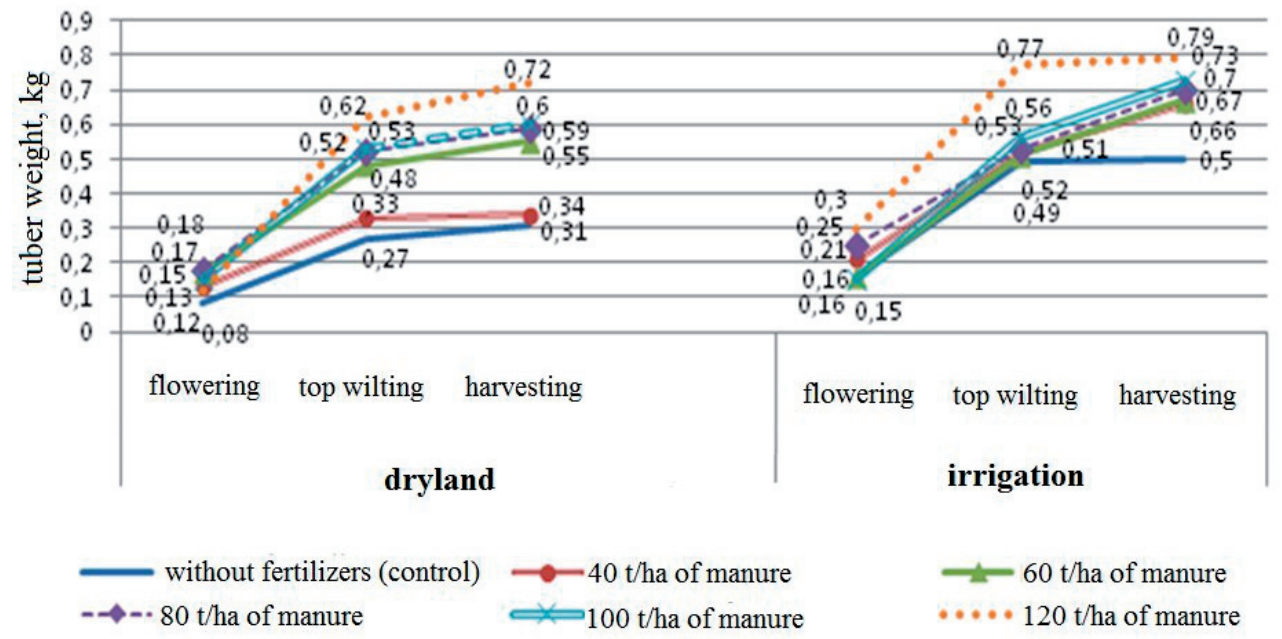

Fig. 2. Dynamics of potato tubers weight when applying different rates of cattle manure, $\mathrm{kg} / \mathrm{plant}$. 


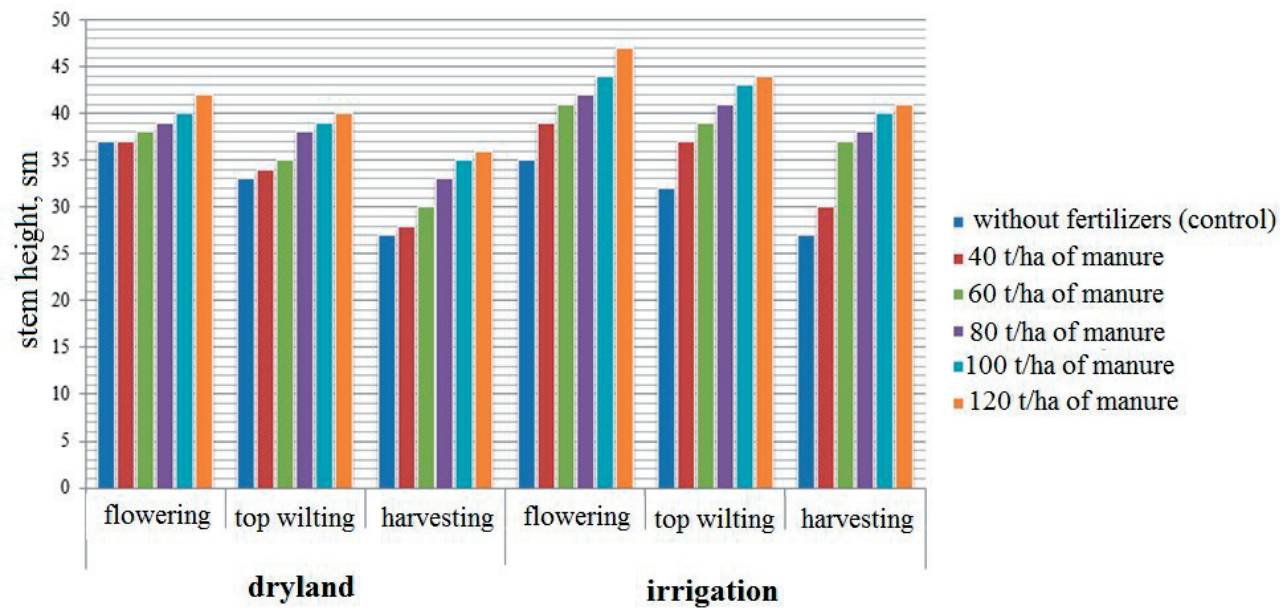

Fig. 3. Dynamics of potato stems height by vegetation phases on irrigated and rainfed areas with the use of cattle manure, $\mathrm{cm}$.

Table 2. Weight dynamics of the above-ground part of potato by vegetation phases on irrigation and dryland, $\mathrm{kg} / \mathrm{plant}$.

\begin{tabular}{|c|c|c|c|c|c|c|}
\hline \multirow{2}{*}{$\begin{array}{c}\text { Type and rate of organic } \\
\text { fertilizers }\end{array}$} & \multicolumn{3}{|c|}{ Dryland } & \multicolumn{3}{c|}{ Irrigation } \\
\cline { 2 - 8 } & Full Blossom & Top wilting & Crop Harvesting & Full Blossom & Top wilting & Harvesting \\
\hline Without fertilizers (control) & 0.17 & 0.09 & 0.02 & 0.18 & 0.25 & 0.03 \\
\hline Manure 40 t/ha & 0.11 & 0.14 & 0.04 & 0.13 & 0.17 & 0.05 \\
\hline Manure 60 t/ha & 0.15 & 0.16 & 0.05 & 0.14 & 0.16 & 0.05 \\
\hline Manure 80 t/ha & 0.17 & 0.21 & 0.10 & 0.18 & 0.26 & 0.10 \\
\hline Manure 100 t/ha & 0.13 & 0.22 & 0.09 & 0.19 & 0.28 & 0.13 \\
\hline Manure 120 t/ha & 0.14 & 0.20 & 0.07 & 0.22 & 0.33 & 0.15 \\
\hline
\end{tabular}

potato tubers ranging from 8 to $29 \%$. This indicator depends on the potato variety [24]. The analyses showed that starch content varied from $16.7 \%$ to $20.8 \%$ with applied cattle manure under dryland at 40 to $120 \mathrm{t} /$ ha. For all the studied variants, the starch content was within optimal limits (Fig. 5).

Cattle manure has a high content of nitrogen being a hazard to human health at exceeding MAC values.

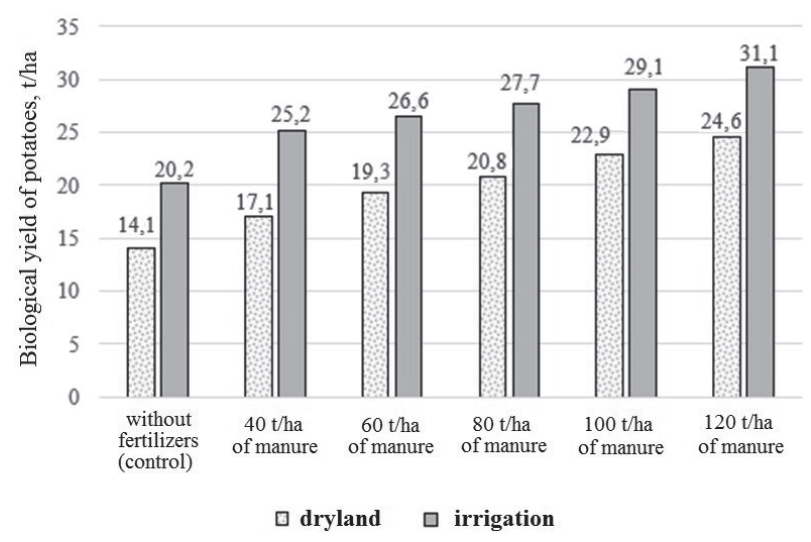

Fig. 4. Biological yield of potatoes depending on the rate of cattle manure, $\mathrm{t} / \mathrm{ha}$.
Laboratory tests showed that the nitrate content was $169.8 \mathrm{mg} / \mathrm{kg}$ on the unfertilized plot under rainfed. Under rainfed conditions, the nitrate content ranged from 186.67 (the rate of applied cattle manure being

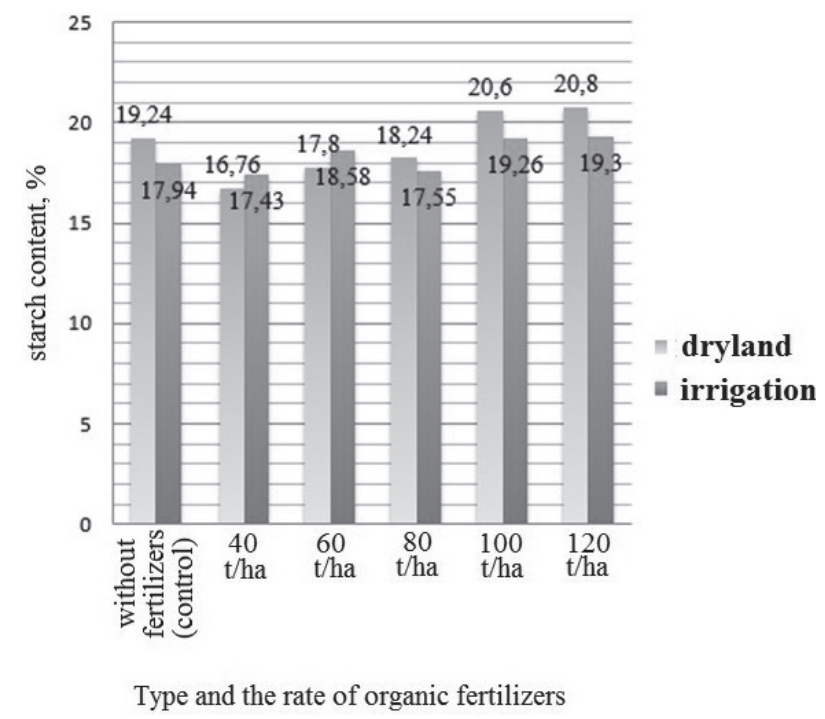

Fig. 5. Starch content in potato tubers depending on the rate of organic fertilizers and irrigation, $\%$. 
Table 3. Biological yield with marketable tuber yield according to the rate of the applied catlle manure.

\begin{tabular}{|c|c|c|c|c|c|c|}
\hline \multirow{2}{*}{$\begin{array}{l}\text { Type and dose of } \\
\text { organic fertilizers }\end{array}$} & $\begin{array}{l}\text { Biological } \\
\text { yield, } t / h a\end{array}$ & $\begin{array}{l}\text { Marketable } \\
\text { value, } \%\end{array}$ & $\begin{array}{l}\text { Marketable tuber } \\
\text { yield, } t / h a\end{array}$ & $\begin{array}{l}\text { Biological } \\
\text { yield, } \mathrm{t} / \mathrm{ha}\end{array}$ & $\begin{array}{l}\text { Marketable } \\
\text { value, } \%\end{array}$ & $\begin{array}{c}\text { Marketable } \\
\text { tuber yield, } \mathrm{t} / \mathrm{ha}\end{array}$ \\
\hline & \multicolumn{3}{|c|}{ dryland } & \multicolumn{3}{|c|}{ irrigation } \\
\hline $\begin{array}{l}\text { Without fertilizers } \\
\text { (control) }\end{array}$ & 14.05 & 42 & 5.90 & 20.16 & 69 & 13.91 \\
\hline Manure $40 \mathrm{t} / \mathrm{ha}$ & 17.07 & 45 & 7.68 & 25.21 & 76 & 19.16 \\
\hline Manure $60 \mathrm{t} / \mathrm{ha}$ & 19.29 & 52 & 10.03 & 26.57 & 74 & 19.66 \\
\hline Manure $80 \mathrm{t} / \mathrm{ha}$ & 20.8 & 67 & 13.94 & 27.71 & 70 & 19.40 \\
\hline Manure $100 \mathrm{t} / \mathrm{ha}$ & 22.9 & 80 & 18.32 & 29.1 & 64 & 18.62 \\
\hline Manure $120 \mathrm{t} / \mathrm{ha}$ & 24.55 & 69 & 16.94 & 31.13 & 59 & 18.37 \\
\hline $\mathrm{HCP}_{05}$ & 0.98 & - & - & 1.33 & - & - \\
\hline
\end{tabular}

$40 \mathrm{t} / \mathrm{ha}$ ) to $210.37 \mathrm{mg} / \mathrm{kg}$ (the rate of applied manure being $120 \mathrm{t} / \mathrm{ha})$. On irrigated land, it varied from 174.26 (the rate of $40 \mathrm{t} / \mathrm{ha}$ ) to $212.32 \mathrm{mg} / \mathrm{kg}$ (the rate of $120 \mathrm{t} / \mathrm{ha}$ ). The received values of nitrate content in all the studied variants of experiments do not exceed the maximum permissible concentration $(250 \mathrm{mg} / \mathrm{kg})$ (Fig. 6).

With market relations between people, economic efficiency is an indispensable condition in any production. It determines the relevance of an issue under discussion and the feasibility of its implementation into the production process. To determine potato production efficiency at different rates of cattle manure and irrigation, production costs, namely spending on soil preparation, transportation, and processing of organic fertilizers, irrigation, etc., are calculated according to the process charts.

Taking into account the level of prices of agricultural products and the associated costs of laborintensive production, the economic efficiency of potato production was analyzed according to the manure (type

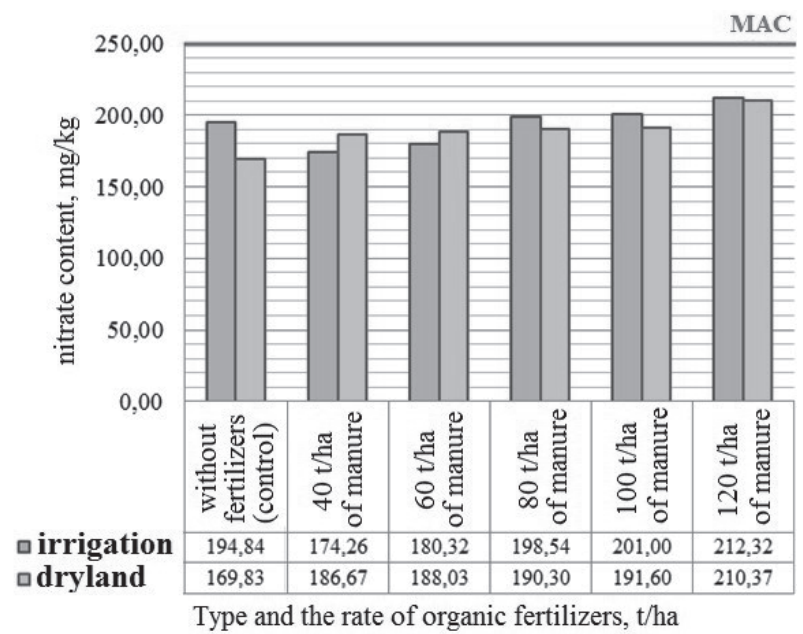

Fig. 6. Nitrate content in potato tubers depending on the rate of cattle manure and irrigation, $\mathrm{mg} / \mathrm{kg}$. and application rate) and the availability of irrigation for an area of 100 ha for average three years. Spending on potato growing. Cattle manure preparation to be applied to the soil, transporting organic fertilizers, and watering is calculated according to the process charts. Marketable tuber yield was adjusted to the technological losses, being taken equal to $20 \%$ at potato harvesting. The selling price of potatoes was 9.0 rubles $/ \mathrm{kg}$. As a result, the highest profit from 1 ha under rainfed was 22.7 thousand rubles received at applying $100 \mathrm{t} / \mathrm{ha}$ of cattle manure. It was 25.2 thousand rubles under irrigation with the manure rate of $80 \mathrm{t} / \mathrm{ha}$.

\section{Discussion}

Potatoes respond well to fertilizer applications $[25,26]$, especially to those rich in nitrogen. Organic fertilizers have proved to increase potato production. Their application has a beneficial effect on yields and provides disposal of cattle manure stored in farmyards.

Overall, the conducted research demonstrates that higher rates of cattle manure used in potato growing as an organic fertilizer increases biological yields of the crop both under irrigation and dryland conditions. Applying $120 \mathrm{t} / \mathrm{ha}$ of manure does not worsen yield indicators and tuber quality. The given rate is not critical. Meanwhile, the marketable value data (Table 3) indicate that $100 \mathrm{t} / \mathrm{ha}$ under dryland and $40 \mathrm{t} / \mathrm{ha}$ under irrigation provide better results. This adjusts biological yields. Vegetative irrigation also contributed to higher biological yields of potatoes by average 1.3 times compared to dryland. Iranian scientists having applied cattle manure for potatoes (at the rate of 5, 10, 15, and $20 \mathrm{t} / \mathrm{ha}$ ), got the highest yield of tubers (36.8 t/ha) with $20 \mathrm{t}$ of animal manure. However, they combined organics with nitrogen at a rate of $150 \mathrm{~kg} / \mathrm{ha}$.

According to the results of domestic and foreign scientists, potato crop yields can reach 40-100 t/ha or more $[27,28]$. There is no doubt that the role of fertilizers varies markedly depending on the biological fertility of the soil, its type, and its variety. When 
a crop gets the primary nutrients from the soil, it is less affected by adverse conditions [29].

According to Boligłowa and Gleń [30], applied manure brings many macroelements to the soil $(525 \mathrm{~kg}$ NPK'ha-1). The researchers claim that animal manure provides a better condition of tubers after the harvest and during the storage compared to other field operations (stubble plowing, barley straw introduction, intercrop planting). Taheri et al. [31] also applied cattle manure (10 and $20 \mathrm{t} / \mathrm{ha}$ ) for potatoes together with zink $(50 \mathrm{~kg} / \mathrm{ha})$. Their results demonstrate that $10 \mathrm{t} / \mathrm{ha}$ of animal manure positively affects the plant dry matter. It increases due to better soil structure and aeration. The scientists claim that the study of 10 and $20 \mathrm{t} / \mathrm{ha}$ of cattle manure does not disclose all the potential of this fertilizer. When zink is applied with manure, there are more small tubers.

Scientists from Damatur State, Nigeria, concluded that the application of manure to meet the nutritional needs of crops would be an inevitable practice in the coming years. Their result on studying manure as a fertilizer to be introduced in the soil is as follows: the physical condition of the soil has improved, chemical and biological indicators have normalized, moisture intensity has increased. All this has led to an increase in crop yield [32].

Cattle manure introduced into the soil creates a favorable environment; plants better absorb nutrients, useful microorganisms that improve soil properties are developed [33, 34].

The rate of manure application, as well as the method of application, are crucial. In field experiments in Texas and Pennsylvania, the United States, the soil was oversaturated with phosphorous having entered from surface fertilizers with the runoff. Manure and phosphorus content in the soil was analyzed within 14-17 months. The manure weight was constantly decreasing, while the total amount of phosphorus was constant. As a result of precipitation, phosphorous was washed out [35].

According to Vasiliev [36], relatively low-cost organic fertilizers, being introduced into the soil, improve the physical, chemical, and mechanical properties of the soil, water, and air regimes, reduce the soil acidity, and its impact on plant growth and useful microorganisms. The results of the given paper claim that (dry) cattle manure is better to be applied during spring cultivation. Scientists from North Wisconsin draw attention to the type of fertilizer introduced into the soil. Liquid animal manure applied just before potato planting reduces the yields (production and quality of some varieties is lower) [37].

In recent years (2002-2016), the average potato yield in the Republic of Bashkortostan was $11.1 \mathrm{t} / \mathrm{ha}$. In very dry 2010 , the potato yield was only $4.1 \mathrm{t} / \mathrm{ha}$, and in dry 2000 and 2012, 6.6 and 6.8 t/ha, respectively. In West Africa (Republic of Ghana), two-thirds of the territory is highly affected by drought during the growing season. Therefore, small farmers in these areas can expect a loss [38]. Timely soil moisture improves its fertility. Regulation of the water regime under the requirements of plants expands the composition of valuable highyielding crops for each zone.

New science-based solutions are required for further development of the potato industry to supply the population with indispensable food and industry with raw material. In the last five years, potato production in Bashkortostan has grown to $270 \mathrm{~kg} /$ person and consumption to $180 \mathrm{~kg} /$ person [39]. To meet the needs of the population of the country in potato, its production should be increased not only by expanding the area under the crop but also by increasing the yield.

\section{Conclusions}

The optimal rates of cattle manure for potatoes cultivated on leached chernozem in the southern foreststeppe of the Republic of Bashkortostan under irrigation and rainfed conditions were found. Potato growing at different rates of cattle manure application has been studied. There is an economic assessment of efficiency to apply different rates of manure.

It has been found that $100 \mathrm{t} /$ ha of cattle manure brings in the highest marketable tuber yield (18.3 t/ha) without irrigation. On the irrigated field, the maximum yield (19.2 t/ha) was received with $40 \mathrm{t} / \mathrm{ha}$ of cattle manure. The highest content of dry matter in tubers $(25.8 \%)$ was at $40 \mathrm{t} / \mathrm{ha}$ under dryland. In conditions of irrigation, it was received with the application rate of $100 \mathrm{t} / \mathrm{ha}(24 \%)$. The highest starch content in potato tubers was at $120 \mathrm{t} /$ ha of manure applied: $20.8 \%$ on dry land and $19.3 \%$ on irrigated land.

To get 15.0-19.6 t/ha yields of organic Nevskiy variety potatoes in conditions of leached chernozem of the southern forest-steppe of Bashkortostan, it is recommended:

1. Under dryland:

- in spring, the soil is rotavated and fertilized with 1 $00 \mathrm{t} / \mathrm{ha}$ cattle manure.

2. In irrigation conditions:

- in spring, the soil is rotavated and fertilized with $80 \mathrm{t} /$ ha cattle manure.

- to ensure optimal soil moisture to perform 1-3 watering with irrigation rate $650-2400 \mathrm{~m}^{3} / \mathrm{ha}$, depending on the degree of moisture in the growing season.

\section{Conflict of Interest}

The authors declare no conflict of interest.

\section{References}

1. ABEGUNDE O.K., MU T.H., CHEN J.W., DENG F.M. Physicochemical characterization of sweet potato 
starches popularly used in Chinese starch industry. Food Hydrocoll, 33 (2), 169, 2013.

2. DREWNOWSKI A., REHM, C.D. Vegetable cost metrics show that potatoes and beans provide most nutrients per penny. PLOS One, 8(5), e63277, 2013.

3. ESPOLOV T., SULEIMENOV Z., ESPOLOV A., MUKASH J., TAZHIGULOVA G., ABDRASHOV S. Agroindustrial complex modernization of Kazakhstan on the basis of innovation. Int. J. Manag. Bus. Res., 8 (1), 93, 2018.

4. ESPOLOV T.I., ESPOLOV A.T., SULEIMENOV Z.Z., OSPANOV B.S., AITUGANOV K.K. Economic Problems of Agricultural Digitalization, Int. J. Manag. Bus. Res., 9 (1), 142, 2019.

5. SHCHERBAKOVA N.A. Promising varieties of potatoes and the technology of their cultivation in the Astrakhan region. Current ecological state of the environment and scientific and practical aspects of environmental management. Proceedings of the I International scientificpractical Internet-conference, dedicated to the $25^{\text {th }}$ anniversary of FSBI "Caspian research Institute of arid agriculture", Solenoe Zaimishche, 1929, 2016.

6. CENTNER T.J. Nutrient Pollution from Land Applications of Manure: Discerning a Remedy for Pollution. Stanford Law and Policy Review, 21, 213, 2010.

7. ONWUDIKE S.U. Effectiveness of cow dung and mineral fertilizer on soil properties, nutrient uptake and yield of sweet potato (Ipomoea batatas) in Southeastern Nigeria Asian J. Agric. Res., 4 (3), 148, 2010.

8. ABDELHAFEZ A.A., ABBAS H.H., ABD-EL-AAL R.S., KANDI N.F., LI J., MAHMOUD W. Environmental and health impacts of successive mineral fertilization in Egypt. Clean - Soil, Air, Water, 40 (4), 356, 2012.

9. MISHRA D., RAJVIR S., MISHRA U., KUMAR S.S. Role of bio-fertilizer in organic agriculture: a review. Res. J. Recent Sci., 2, 37, 2013.

10. SAVCI S. An agricultural pollutant: chemical fertilizer. Int. J. Environ. Sci. Devel., 3 (1), 77, 2012.

11. GAMAYUNOVA V.V., ISKAKOVA O.S. Yields and appearance of bulbs of cardboard strip gardening are cumulatively influenced by the factors of cultivation. Sci. Rev, 3 (24), 1, 2016.

12. MANNING D.A. Mineral sources of potassium for plant nutrition. A review Agron. Sustain. Dev., 30 (2), 2814, 2010.

13. GOULDING K.W.T. Soil acidification and the importance of liming agricultural soils with particular reference to the United Kingdom. Soil Use Manage, 32 (3), 390, 2016.

14. KHAIBULLIN M.M., KIRILLOVA G.B., YUSUPOVA G.M., KAGIROV E.S., ISMAGILOV R.Z., RACHIMOV R.R., SERGEEV V.S., KHAZIEV F.H., GAIFULLIN R.R., BAGAUTDINOV F.Y. Influence of percentage fertilizer systems on change of agrochemical properties of the arable layer of leach Chernozem and on the crops productivity of crop rotation J. Eng. Appl. Sci., 13, 6527, 2018.

15. TAN Z.X., LAL R., WIEBE K.D. Global soil nutrient depletion and yield reduction. J. Sustain. Agr., 26 (1), 123, 2005.

16. ADEWUMI A.A., ADEWUMI I.K., OLALEYE V.F. Livestock waste-menace: Fish wealth-solution. Afr. J. Environ. Sci. Technol, 5 (3), 149, 2011.

17. O'CALLAGHAN J.R., DODD V.A., POLLOCK K.A.. The long-term management of animal manures J. Agric. Eng. Res., 18 (1), 1, 1973.

18. WHALEN J.K.,CHANG C., CLAYTON G.W., CAREFOOT J.P.. Cattle manure amendments can increase the $\mathrm{pH}$ of acid soils. Soil Sci. Soc. Am. J., 64 (3), 962, 2000.

19. BALEMI T. Effect of integrated use of cattle manure and inorganic fertilizers on tuber yield of potato in Ethiopia. J. Soil Sci. Plant Nutr, 12 (2), 253, 2012.

20. NAJM A.A., HADI M.R.H.S., FAZELI F., DARZI M.T., RAHI A. Effect of integrated management of nitrogen fertilizer and cattle manure on the leaf chlorophyll, yield, and tuber glycoalkaloids of Agria potato. Commun. Soil Sci. Plant Anal., 43 (6), 912, 2012.

21. MUSAEV M.R. Organic fertilizers and quality of potato tubers in the foothills subprovince of the Republic of Dagestan. News of Dagestan SPU, 1 (18), 43, 2012.

22. DOSPEKHOV B.A. Field Experience Method. Moscow, 1985.

23. ZAKHARIKHINA L.V., BURTOVOY A.V. Anthropogenic Evolution of Zheltozems in the Sochi Sanatorium Area. Eurasian Soil Science, 53(6), 820, 2020.

24. MUSHINSKY A.A., AMINOVA E.V., GERASIMOVA E.V. Selection of medium-early and medium-ripe potato varieties for the steppe zone of the southern Urals. Bull. Samara State Agricult. Acad., 1 (4), 18, 2016.

25. ČERNY J., BALIK J., KULHANEK M., ČASOVA K., NEDVED V. Mineral and organic fertilization efficiency in long-term stationary experiments. Plant Soil Environ, 56 (1), 28, 2010.

26. KUMAR M., BAISHAYA L.K., GHOSH D.C., GUPTA V.K., DUBEY S.K., DAS A., PATEL D.P. Productivity and soil health of potato (Solanum tuberosum L.) field as influenced by organic manures, inorganic fertilizers and biofertilizers under high altitudes of eastern Himalayas. J. Agric. Sci., 4 (5), 223, 2012.

27. LUTALADIO N., CASTALDI L. Potato: The hidden treasure. J. Food Compost. Anal., 22 (6), 491, 2009.

28. ZHUCHENKO A.A. Adaptive crop production. Theory and practice: in 3 volumes; Agrorus Publishing: Moscow, 1, 815, 2008.

29. VLADIMOROV S.V. Efficiency of increased rates of mineral and organic fertilizers in potato growing under the forest steppe conditions of the Middle Volga region. Bull. Kazan State Agrar. Univ., 8 (3), 92, 2013.

30. BOLIGLOWA E., GLEN K. Yielding and quality of potato tubers depending on the kind of organic fertilization and tillage method. Electron. J. Pol. Agric. Univ., 6 (1), 2003.

31. TAHERI N., SHARIF-ABAD H.H., YOUSEFI K., ROHOLLA-MOUSAVI S. Effect of compost and animal manure with phosphorus and zinc fertilizer on yield of seed potatoes. Soil Sci. Plant Nutr., 12 (4), 705, 2012.

32. BASHIR A.Y., LIMAN Y.M., ZANGOMA I.M. Effect of different source of organic manure on the growth and yield of irrigated onion in Damaturu Local Government Area of Yobe State, Nigeria. . Int. J. Multidiscip. Res. Dev., 3 (4), 23, 2015.

33. DUNJANA N., NYAMUGAFATA P., SHUMBA A., NYAMANGARA J., ZINGORE S. Effects of cattle manure on selected soil physical properties of smallholder farms on two soils of Murewa, Zimbabwe. Soil Use Manage, 28 (2), 221, 2012.

34. MOORE A.D., OLSEN N.L., CAREY A.M., LEYTEM A.B. Residual effects of fresh and composted dairy manure applications on potato production. Am. J. Potato Res., 88 (4), 324, 2011.

35. VADAS P.A., HARMEL R.D., KLEINMAN P.J.. Transformations of soil and manure phosphorus after surface application of manure to field plots. Nutr. Cycling Agroecosyst., 77(1), 83-99, 2007. 
36. VASILIEV A.A. Influence of sapropel on the yield of potatoes and the fertility of leached chernozems. Bull. Perm Agr. Univ., 1 (5), 3-, 2014.

37. CURLESS M.A., KELLING K.A., SPETH P.E., STEVENSON W.R., JAMES, R.V.. Effect of manure application timing on potato yield, quality, and disease incidence. Am. J. Potato Res., 89 (5), 363, 2012.
38. ATAMPUGRE G., NURESEY-BRAY M., ADADE R. Using geospatial techniques to assess climate risks in savannah agroecological systems. Rem. Sens. Appl: Soc. Environ., 14, 100, 2019.

39. ANDRIANOV A.D. Potato production of Bashkortostan Republic. Interregional Information and Analytical Journal for Agribusiness Professionals 'Cartofelnaia systema', 3, 6, 2016. 